\title{
INOVASI PENGELOLAAN ZAKAT DI ERA DIGITAL (STUDI AKSES DIGITAL DALAM PENGUMPULAN ZAKAT)
}

\section{Holilur Rahman}

Institut Dirosat Islamiyah Al-Amien Prenduan Sumenep Madura

holilur.rahman@idia.ac.id

\begin{abstract}
Abstrak:
Potensi pengumpulan zakat di Indonesia senantiasa berkembang, namun tidak berbanding lurus dengan hasil pengumpulannya. Kondisi objektif covid-19 yang memaksa masyarakat tidak berinteraksi langsung berefek terhadap perubahan gaya hidup masyarakat yang digitalis. Hal tersebut dijadikan landasan bagi institusi amil zakat untuk terus melakukan inovasi pengumpulan zakat. Strategi yang dilakukan institusi amil zakat khususnya Badan Amil Zakat Nasional dengan memanfaatkan platform digital dengan berbagai inovasi yang berkolaborasi dengan mitra fundraising. Tujuan penelitian ini untuk mengetahui inovasi institusi amil zakat dalam mengoptimalkan pengumpulan zakat di era digital. Metode penelitian ini menggunakan jenis penelitian kualitatif yang bersifat deskriptif analitis. Adapun hasilnya menunjukkan bahwa inovasi pengumpulan zakat digital dengan mempermudah muzakki dalam menunaikan zakat dapat meningkatkan pengumpulan zakat secara optimal.
\end{abstract}

Kata Kunci: inovasi, era digital, pengumpulan zakat

\begin{abstract}
:
The potential for zakat collection in Indonesia is always growing, but it is unproportional to the results of the collection. The objective conditions of COVID-19 which force people to indirect interaction have an effect on changes in the lifestyle of the digitalist society. This is used as the basis for the amil zakat institution to continue to improvise zakat collection. The strategy carried out by amil zakat institutions, especially the National Amil Zakat Agency, is by utilizing digital platforms with various innovations in collaboration with fundraising partners. The purpose of this study was to determine the innovations of the amil zakat institution on optimizing zakat collection in the digital era. This research method uses a type of qualitative research that is descriptive analytical. The results show that innovations of digital zakat collection by facilitating muzakki in paying zakat can increase zakat collection optimally
\end{abstract}

Keywords: innovations, digital era, zakat collection 


\section{DIROSAT \\ Journal of Islamic Studies \\ Volume 6, No. 22021}

ISSN: 2541-1667 (print); 2541-1675 (online)

\section{Pendahuluan}

Sesungguhnya zakat merupakan salah satu solusi untuk mengurangi beban ekonomi bagi masyarakat yang terdampak ekonomi. Zakat memiliki peran penting dan menjadi instrumen Islam dalam pengembangan ekonomi sekaligus sebagai jaminan sosial bagi ummat Islam. ${ }^{1}$ Kewajiban ini ditetapkan dalam Islam sebagai salah satu rukun Islam dengan memanfaatkan seluruh lapisan masyarakat muslim. Adanya solusi unt uk mengurangi beban ekonomi bagi masyarakat merupakan fungsi zakat. Oleh karena itu zakat menjadi hal yang substansi bagi adanya perlindungan terhadap masyarakat. ${ }^{2}$ Itulah makna zakat dalam menjadi perlindungan atau jaminan ketika dalam kondisi tidak normal atau terjadi wabah penyakit. Sehingga tidak berlebihan dengan pernyataan Islam merupakan agama pertama yang menjamin umatnya. Hal ini karena ada program zakat.

Berdasarkan hasil penghitungan BAZNAS bahwa potensi zakat tahun 2020 sebesar 330 triliyun sementara capaiannya hanya sekitar 12 triliyun. ${ }^{3}$ Sementara pengumpulan Zakat Infak Shadaqah yang tidak melalui Organisasi Pengumpul Zakat (OPZ) resmi pada sebesar Rp 61 triliyun. ${ }^{4}$ Adapun pengumpulan zakat secara digital melalui e-commerce di tahun 2019 sebanyak 30\% sementara di tahun 2020 diperkirakan naik menjadi 50\%. ${ }^{5}$ Menurut Arifin, Direktur Utama BAZNAS bahwa pengumpulan zakat digital sebanyak Rp 41 Miliar pada tahun 2019, dari jumlah target sebesar Rp40 Miliar. ${ }^{6}$ Hal ini ini memberikan makna bahwa penerimaan zakat dengan cara digital semakin diminati oleh masyarakat apalagi dalam kondisi pandemik virus covit 19. Oleh karena itu strategi penghimpunan zakat oleh badan amil zakat nasional senantiasa dilakukan dengan inovasi pengumpulan zakat.

Adanya data pertumbuhan pengumpulan zakat oleh Badan Amil Zakat Nasional yang berkolaborasi dengan Lembaga Amil Zakat (LAZ) dapat dinilai responsif terhadap perkembangan situasi dan kondisi yang ada. Hal ini juga berarti bahwa BAZNAS yang dilahirkan oleh Negara dan LAZ yang didirikan oleh masyarakat juga melakukan strategi penghimpunan zakat yang serupa yakni dengan cara penghimpunan secara intensif. Hal ini bermakna bahwa penghimpunan tidak hanya secara manual tetapi juga secara digital. Ketika masyarakat tidak bisa melakukan aktivitas berkerumun di publik maka salah satu bentuk pengumpulan zakat secara e-commerce menjadi salah satu solusi di dalam pengumpulan zakat.

Institusi amil zakat baik BAZNAS maupun LAZ perlu penentuan sumber komunikator dalam menerapkan daerah fundraising dan juga indirect fandraising. ${ }^{7}$ Karena menentukan sumber komunikator baik pesan media sasaran komunikasi

\footnotetext{
${ }^{1}$ Sayyid Quṭb, al 'Adālah al Ijtimāị̂yah fì al Islām, Cet. VI (Bayrūt: Dār al Shurūq, 1979), 35.

${ }^{2}$ Holilur Rahman, Regulasi Zakat: Studi Kewenangan Amil Zakat Di Indonesia (Tangerang Selatan: Yasmi, 2018), 80.

${ }^{3}$ https://www.idntimes.com/business/economy/vanny-rahman/potensi-zakat-di-indonesia-mencapairp330-triliun/1.

${ }^{4}$ https://baznas.go.id.

${ }^{5}$ https://cafonline.org

${ }^{6}$ https://baznas.go.id/Press Release/baca/BAZNAS Ajak Masyarakat Zakat Digital/531

${ }^{7}$ Nur Rohim, Ade. Optimalisasi Penghimpunan Zakat Melalui Digital Fundraising. Al- Balagh: Jurnal Dakwah dan Komunikasi. 4.Vol. 1. (2019). 740.
} 


\section{DIROSAT \\ Journal of Islamic Studies \\ Volume 6, No. 22021}

ISSN: 2541-1667 (print); 2541-1675 (online)

merupakan salah satu indikator dalam proses intensifikasi pengumpulan zakat lebih daripada itu institusi zakat di Indonesia baik BAZNAS maupun LAZ tidak bisa menghilangkan metode pengumpulan zakat secara manual sehingga yang dilakukan adalah mengintegrasikan penghimpunan zakat secara manual dan digital tentu proses dan strategi pengumpulan ini masih menjadi primadona karena masyarakat di era revolusi 4.0 ini masih proses transisi.

Penelitian inovasi pengelolaan zakat khususnya dalam pengumpulan zakat masih menyesuaikan dengan kondisi masyarakat atau segmentasi Muzakki. Adapun proses penyesuaiannya berupa perkembangan sistem informasi digital. Karena bagaimanapun juga kondisi perekonomian harus tetap berjalan. Karena hal itu, menjadi bagian dari maqashid syariah yaitu hifdh al-mal (menjaga harta). ${ }^{8}$

Selanjutnya pada masa pandemi covid 19 peningkatan penerimaan zakat secara online di Indonesia terus tumbuh dan berkembang hal ini dikenal dengan pemakai ecommerce baik di sistem transaksi online maupun di perbankan online bertumbuhnya perusahaan e-commerce dengan memiliki fitur dalam membayar zakat dengan bertumbuhnya e-commerce tentu hal ini berpengaruh positif terhadap pengumpulan zakat berdasarkan hasil penelitian bahwa di masa pandemik tahun 2020 ternyata pengumpulan zakat dalam kondisi pandemik tersebut dengan menggunakan fasilitas ecommerce justru naik signifikan

Selanjutnya bentuk model strategi pengumpulan zakat infaq dan shodaqoh harus sesuai dengan ketentuan Syariah dan Undang-Undang dengan mengikuti protokol penanganan Covid 19. Hal ini menjadi penting dilakukan karena adanya strategi pengumpulan sah atau tidaknya maka harus kembali kepada ketentuan Syariah sementara Undang-Undang akan menjadi pendukung di dalam merealisasikan prinsipprinsip yang ada di dalam syariah sehingga sesuatu yang sifatnya belum sempurna tanpa diwajibkan maka sesuatu itu bisa menjadi wajib sebagaimana kaidah māla yatimmu alwājib illa bihi fahuwa wäjib (sesuatu yang wajib tidak bisa sempurna kecuali dengan sesuatu itu, maka sesuatu itu wajb hukumnya) pelaksanaan fatwa MUI Nomor 23 tahun 2020 tentang Penggunaan Zakat Infaq Dan Shodaqoh dilakukan dengan menggunakan metodologi penetapan fatwa dengan berbagai pertimbangan hukum yang jelas.

Penelitian ini bertujuan menjelaskan dan menganalisis berbagai model pengelolaan zakat di era digital khususnya dalam akses digital pengumpulan zakat. lebih daripada itu model-model di dalam pengumpulan zakat khususnya di era digital di era pandemi covid 19 akan menjadi satu analisis yang akan dilakukan dalam penelitian ini khususnya berkaitan dengan kondisi masyarakat ketika terbatas dalam melakukan aktivitas aktivitas umum bahkan dilarang beraktivitas di luar serta dilarang berkerumun. Hal ini demikian perlu dilakukan analisis sejauh mana akses digital dalam pengumpulan zakat bisa memberikan pelayanan kepada Muzakki didalam menyerahkan zakatnya kepada amil zakat dalam kondisi demikian maka diperlukan akses yang yang lebih mudah oleh Muzakki untuk menyerahkan zakatnya kepada amil zakat, sejauh mana amil zakat menyiapkan kemudahan dalam pelayaan pengumpulan zakat. Hal ini menjadi penting mengingat era ini adalah era digital dan ini juga masa pandemik sehingga dua

${ }^{8} \mathrm{Abū}$ Ishạà as-Shātibìi, al-Muwāfaqāt fî̀ Ușūl al-Sharī‘ah, vol. 2 (Cairo: al-Maktabah al-Tijānìyah alKubrā, 1975), 6-7.

${ }^{9}$ A. Djazuli, Kaidah-Kaidah Fiqh, cet. 3 (Jakarta: Kencana 2010), 96. 
kondisi yang sangat menentukan ini perlu dilihat sejauh mana akses digital dalam pengumpulan zakat ini bisa berjalan optimal.

\section{Metode Penelitian}

Jenis penelitian ini kualitatif dengan pendekatan studi pustaka. Adapun sumber literatur dalam penelitian ini antara lain menggunakan kitab ilmiah, jurnal ilmiah, artikel di media online dan website serta pernyataan para praktisi di bidang pengumpulan zakat yang dimuat di berbagai media. Adapun analisis penelitiannya dengan menggunakan konten deskriptif pada model penghimpunan zakat baik yang konvensional maupun digital yang dikenal dengan e-commerce.

\section{Hasil dan Pembahasan \\ Model Pengelolaan Zakat}

Pengelolaan zakat dalam era kontemporer menjadi eksperimen yang beragam. Dari aspek model pengelolaan zakat oleh negara terdapat dua tipe: ${ }^{10}$ Pertama, obligatory, yakni model negara atau lembaga resmi yang ditunjuk untuk mengelola zakat dapat memaksakan pembayaran zakat kepada muzaki berdasarkan ketentuan Undang-Undang. Umumnya negara yang menerapkan sistem ini adalah negara yang menjadikan syariát Islam sebagai hukum dasar di negaranya, seperti Saudi Arabia, Libya, Pakistan, Yaman, Sudan dan Malaysia. ${ }^{11}$ Kedua, penerapan non obligatory, yakni model berdasarkan kesukarelaan. Negara-negara yang masuk dalam kategori ini umumnya adalah negara yang mayoritas penduduknya adalah pemeluk agama Islam tetapi hukum Islam tidak menjadi landasan dasar negara dan pemerintahannya, seperti Mesir, Kuwait, Banglades, Yordania, Afrika Selatan dan Indonesia. ${ }^{12}$ Kedua sistem ini dapat dilihat dari sudut pandang filosofis, yuridis dan sosiologis. ${ }^{13}$ Indonesia dalam hal ini termasuk dalam kategori yang kedua, karena walaupun ada perraturan perundang-undangan tentang zakat namun isinya tidak memaksa pembayaran zakat, namun lebih pada kesukarelaan.

Dari segi pengaturan zakat secara umum dapat diklasifikasikan menjadi dua: pertama, pengelolaan yang dipayungi oleh Undang-Undang dan ini ada dua tipe: satu, pengelolaan murni oleh pemerintah; dua, dikelola oleh lembaga yang mendapat legalitas dari pemerintah. Kedua, pengelolaan yang alami tanpa ada payung perundang-undangan yang dalam hal ini diperankan oleh lembaga-lembaga Islam maupun organisasi masyarakat Islam. ${ }^{14}$ Indonesia dalam hal ini memilih tipe pertama, di mana lembaga

\footnotetext{
${ }^{10}$ Monzer Kahf, “Applied Institutional Model for Zakah Collection and Distribution in Islamic Coutries and Communities". Dalam Ahmed Abdel Fattah el-Ashker and M. Sirajul Haq (Eds), Intitutional Framework of Zakah: Dimension and Aplications (Jeddah: IRTI-IDB, 1995), 197-228.

${ }^{11}$ Lihat, Abidin Ahmad Salama, Obligatory vs Nonobligatory Zakah System, Institusional Framework of Zakah: Dimension and Applications (Jeddah: Islamic Research and Training Institute of Islamic Development Bank, 1990), 151.

${ }^{12}$ Ibid.

${ }^{13}$ Rika Isvadiary, "Penerapan Obligatory System Dalam Pengelolaan Zakat Di Indonesia”, Jurnal Syari 'ah LKIHI, Edisi II (Depok: LKIHI-FHUI, 2010) 61-66.

${ }^{14}$ Mundhir Qoḥ, "Tahṣil wa Tawzì' al Zakāh Tajrubah al Mamlakah al 'Arabiyah al Su'ūdiyah" dalam al Mawād al 'Ilmīyah li Barnāmij al Tadrīb 'Alā Taṭbiq al Zakāh fí al Mujtama' al Islāmī al Mu'ạsir (Jedah: al Bank al Islāmi li al Tanmìyah, 1983), 338. Bandingkan dengan tiga model pengelolaan zakat di negara muslim. Pertama, Full Goverment (Obligatory), pengelolaan zakat diakomodasi oleh regulasi negara
} 
pengelola zakat ada yang murni didirikan oleh pemerintah dan ada lembaga yang lahir atas prakarsa masyarakat yang kemudian disahkan oleh pemerintah.

Secara spesifik pengelolaan zakat sesungguhnya terdapat lima model, yaitu: ${ }^{15}$ (i) sistem pengumpulan zakat secara wajib oleh negara; (ii) pengumpulan zakat secara wajib, namun dilakukan oleh masyarakat atau swasta; (iii) pengumpulan zakat secara sukarela oleh negara; (iv) pengumpulan zakat secara sukarela oleh swasta; dan (v) pengumpulan zakat secara sukarela di tingkatan individual, tanpa pengelolaan secara kolektif sama sekali.

Model sistem obligatory dalam implementasinya beragam. Cakupan harta yang wajib dibayarkan zakatnya di Yaman, mencakup zakat fitrah dan zakat mal. Di Arab Saudi, Libya, Pakistan, Yaman, dan Sudan, kewajiban zakat hanya mencakup zakat mal. Adapun di Malaysia kewajiban zakat berlaku pada zakat fitrah dan zakat mal. Perat uran mengenai harta yang terkena zakat mal juga beragam. Di Sudan dan Yaman, zakat mal dikenakan atas bentuk-bentuk harta yang termaktub dalam aturan fikih; di Arab Saudi zakat mal dikenakan atas hasil-hasil pertanian, peternakan, dan barang-barang yang dapat diperdagangkan; di Pakistan zakat mal dikenakan atas aset keuangan dan moneter serta hasil pertanian. ${ }^{16}$

Sementara dalam sistem non obligatory, terdapat tiga model pengelolaan zakat dalam sistem sukarela. ${ }^{17}$ Pertama, pengelolaan zakat oleh lembaga amal swadaya masyarakat, yang banyak terdapat di berbagai negara dan komunitas muslim. Pemerintah dapat mengontrol lembaga ini sebagaimana kontrol terhadap lembaga nirlaba lainnya.

Kedua, pengelolaan zakat oleh lembaga semi pemerintah yang menghimpun zakat secara sukarela dan menyalurkan zakat tersebut kepada mereka yang berhak. Contohnya Nasser Social Bank di Mesir. Pengelolaan zakat ini, bank mendirikan departemen khusus untuk zakat. Bank menerima zakat melalui panitia zakat lokal atau pembayaran langsung ke kantor dan cabang bank.

Ketiga, pengelolaan zakat oleh lembaga pemerintah yang secara khusus didirikan oleh negara untuk menerima dan menyalurkan zakat. Beberapa negara mendirikan lembaga pengelola zakat yang secara hukum dan financial adalah independen, seperti Kuwaitī Zakat House (bayt al-zakāt) tahun 1982, Zakat Fund (sundūk al-zakât) di Yordania (1978), Bahrayn (1979), Tunisia dan Bangladesh.

dengan mewajibkan seluruh muslim untuk berzakat. Model ini diterapkan oleh Arab saudi, Sudan, Brunai dan Malaysia (Kedah). Kedua, institution that cooperation with goverment, (Voluntary), Pengelolaan zakat yang diakomodasi dengan regulasi negara namun tidak mewajibkan muslim untuk berzakat. Model ini diterapkan oleh Indonesia, Malaysia (kecuali Kedah), Bosnia Herzegovina, Pakistan. Ketiga, NonGoverment Organization, pengelolaan zakat yang tidak diat ur melalui regulasi negara. Model ini terdapat pada: India, Nigeria, Afrika Selatan.

${ }^{15}$ I.a Imtiazi .et al. (eds), Management of Zakah in Modern Muslim Society (Jeddah: IRTI-IDB, 1989), dan Ahmed Abdel Fattah el-Ashker and M. Sirajul Haq (Eds), Intitutional Framework of Zakah: Dimension and Aplications (Jeddah: IRTI-IDB, 1995).

${ }^{16} \mathrm{Abu}$ al-Hasan Sadeq, "A Survey of the Intitutional Of Zakah: Issues, Theories and Administration" (Jeddah: IRTI-IDB, 1994) 45

${ }^{17}$ Yusuf Wibisono, Mengelola Zakat Indonesia Diskusi Pengelolaan Zakat Nasional Dari Rezim UndangUndang Nomor 38 Tahun 1999 ke Rezim Undang-Undang Nomor 23 tahun 2011 (Jakarta: Kharisma Putra Utama, 2015) 151. 


\section{DIROSAT \\ Journal of Islamic Studies \\ Volume 6, No. 22021}

ISSN: 2541-1667 (print); 2541-1675 (online)

Sementara, Beik ${ }^{18}$ mengkatagorikan tiga tipologi sistem perzakatan yang ditinjau dari regulasi dan kewajiban berzakat berdasarkan hukum positif. Tiga tipologi sistem perzakatan tersebut meliputi model komprehensif, model parsial, dan model sekuler.

Pertama, model komprehensif memiliki tujuh karakteristik yang meliputi: (i) memiliki Undang-Undang zakat; (ii) zakat menjadi instrumen wajib dalam hukum positif; (iii) adanya standarisasi sistem pengelolaan zakat; (iv) terdapat ketentuan obyek zakat; (v) struktur kelembagaan; (vi) adanya integrasi zakat dan fiskal; (vii) diterapkan good amil governance. Arab Saudi dan Malaysia masuk dalam kategori ini.

Kedua, model pengelolaan zakat parsial. Model ini diterapkan oleh suatu negara yang memiliki aturan formal yang mengatur tentang perzakatan, namun belum menjadikan zakat sebagai kewajiban dalam hukum positif. Pada model ini lebih ditekankan pada aspek kelembagaan dan sistem pengelolaan zakat. Zakat masih berada pada instrumen yang bersifat kerelaan. Kerangka regulasi diat ur sedemikian rupa untuk menghasilkan tata kelola zakat yang baik. Indonesia, Mesir, Kuwait termasuk dalam kategori ini.

Ketiga, model sekuler. Negara yang menerapkan model ini menganggap bahwa zakat adalah urusan pribadi masyarakat sehingga tidak ada intervensi pemerintah maupun regulasi terhadap institusi zakat. Semua urusan pengelolaan zakat diserahkan pada institusi sosial kemasyarakatan. Negara tidak ikut mengatur karena anggapan bahwa urusan agama harus dipisahkan dari urusan politik dan pemerintahan. Maroko, Turki, Oman termasuk dalam kategori ini.

Oleh karena itu, adanya amil menjadikan proses pelaksanaan zakat lebih teratur dan sistematik. Di negara minoritas muslim, berbagai badan, yayasan, atau perusahaan didirikan langsung oleh komunitas muslim untuk mengurus zakat. ${ }^{19}$ Oleh karena amil terlibat dalam suatu bentuk pengurusan aset yang kompleks, dalam skala yang besar dan kadangkala bersifat nasional, maka amil yang tidak sesuai dianggap sebagai tugas individu secara pribadi, tetapi dalam bentuk sebuah organisasi besar yang teratur. Inilah asas adanya pembentukan istilah amil korporat. ${ }^{20}$ Di negara sekuler pengumpulan dana sosial keagamaan dikenal dengan filantropi.

Di negara yang menganut paham sekuler, warga muslim tetap bisa menunaikan zakat sebagai ibadah sesuai dengan keyakinan agamanya. Tetapi di negara-negara sekuler karena pemerintah tidak mengurus kehidupan beragama atau tegasnya negara tidak mengatur masalah zakat dalam hukum positif, maka fungsionalisasi zakat lebih berkembang dalam ranah filantropi semata. Menurut Am. Saifuddin, ${ }^{21}$ menyatakan begitu besar peran strategis zakat, maka sifat imperatif zakat harusnya mempunyai daya paksa yang lebih kuat dari para pengumpul zakat. Maka pelaksanaan pengumpulan zakat memerlukan aspek legal dari negara melalui regulasi zakat.

Di Amerika Serikat pengelolaan filantropi berperan cukup dominan dalam pembentukan civil society. Mengingat orang beragama merupakan jumlah mayoritas

\footnotetext{
${ }^{18}$ BAZNAS, Arsitektur Zakat Indonesia (Jakarta: Pusat Kajian Strategis BAZNAS, 2017) 13.

${ }^{19}$ Mujani Tarimin, Tanggungjawab Amil dalam Konteks Kontemporari, Kertas Kerja 10, Zakat Menuju Pengurusan Profesional (Kualalumpur: Utusan Publications \& Distributor, 2005) 135.

${ }^{20}$ Hasan Bahrom \& EzaniYaaqub, Pengurusan Zakat Semasa (Shah Alam: Pusat Penerbitan Universuti (UPENA) UiTM, 2006) 46-47.

${ }^{21}$ AM Saefuddin, Membumikan Ekonomi Islam (Jakarta: PT. PPA Consultants, 2011) 109.
} 
maka pengumpulan dana filantropi sesuai dengan ajaran mereka. Dalam agama Kristen terdapat tuntunan untuk menyumbang sebesar $10 \%$ dari pendapatan (titthe atau sepersepuluh) menjadi kewajiban agama. Ismartono, mengatakan bahwa ajaran tentang pengadilan terakhir dan orang Samaria yang murah hati sering dipakai untuk dasar aktivitas filantropi kristiani. Survei yang dilakukan di Amerika Serikat. ${ }^{22}$

Religius giving adalah aktivitas kedermawanan sosial yang diberikan kepada lembaga keagamaan atau dari dan oleh komunitas agama tertentu. Dalam ajaran agama kedermawanan ada yang berupa himbauan umum (seperti mengasihi dan menyantuni fakir miskin), dan ada yang berupa kegiatan khusus yang dianggap sebagai kewajiban agama [seperti zakat, titthe (Kristen), Dana (Hindu dan Budha), ${ }^{23}$ sedekah (Yahudi) ${ }^{24}$ ]. Seorang beragama bisa melakukan religius giving dan non religius giving (secular giving).

Survei yang dilakukan oleh Independent Sector di Amerika Serikat, menyatakan bahwa religius giving jauh lebih besar daripada secular giving. Tidak hanya itu, masyarakat yang menyumbang untuk tujuan religious rupanya mereka juga menyumbang untuk hal-hal yang non religious lebih besar dari sumbangan dari kelompok sekuler. ${ }^{25}$

Perbandingan sumbangan dari orang agamis dan sekuler di AS lebih memperjelas peranan religious giving dalam skala nasional bisa dikatakan bahwa orang beragama yang jumlahnya 33\% dari penduduk AS, berkontribusi sebesar $52 \%$ dari sumbangan nasional. Sedangkan orang sekuler yang berjumlah $26 \% \%$ dari populasi berkontribusi sebesar $13 \%$ dari total dumbangan nasional. Adapun rata-rata sumbangan orang beragama adalah $\$ 2.210$ pertahun, sedangkan rata-rata sumbangan orang sekuler adalah $\$ 642$ pertahun. $^{26}$

\section{Inovasi Pengumpulan Zakat Digital}

Menurut Hasan Bahrom \& Ezani Yaaqub dan PEBS-FEUI menyimpulkan tiga faktor yang mempengaruhi pengumpulan zakat antara lain: ${ }^{27}$ Pertama, akuntabilitas amil zakat. Kepercayaan masyarakat akan tanggung jawab dan keterbukaan amil khususnya dalam pelaporan merupakan faktor yang signifikan dalam pengumpulan zakat.

\footnotetext{
${ }^{22}$ Ismartono, "Filantropi dalam Dunai Kristen" dalam Idris Thaha, (ed.) Berderma Untuk Semua, Praktik dan Wacana Filantropi Islam (Jakarta: Teraju 2003) 81-90.

${ }^{23}$ Mark Juegensmeyer dan Darrin McMahon, Philantropy in the World's Traditions (Bloomington: Indoana University Press, 1998) 263-178.

${ }^{24}$ Alter F. Landesman, Jewish Social Work Today Religion and Social Work (New York: The Institut for Religious and Social Studies, 1956) 51.

${ }^{25}$ Independent Sector, Giving and Volunteering un the United States (Washington D.C.: Independent Sector, 2001).

${ }^{26}$ Amelia Fauzia, "Religius Giving di Indonesia: Studi Kasus Filantropi Islam”, Dialog Jurnal Penelitan dan Kajian Keagamaaan, No. 69, 2010, 53-64.

${ }^{27}$ Abdulloh Mubarok dan Baihaqi Fanani, "Penghimpunan Dana Zakat Nasional: Potensi, Realisasi dan Peran Penting Organisasi Pengelola Zakat”, PERMANA, Vol . V No.2, 2014, 14. Bandingkan, PEBSFEUI. 2011, Indonesia Shari'ah Economic Outlook (ISEO) (Jakarta: Lembaga Penerbit FEUI, 2011). Menurut M. Amin Rais ada dua sebab tidak optimalnya pengumpulan zakat: pertama, para wajib zakat belum sadar kewajiban agamanya, kedua, mereka sudah sadar, tetapi enggan karena tidak percaya penuh pada amil zakat. M. Amin Rais, Tauhid Sosial Formula Menggempur Kesenjangan (Bandung: Mizan, 1998) 133.
} 


\section{DIROSAT}

Journal of Islamic Studies

Volume 6, No. 22021

ISSN: 2541-1667 (print); 2541-1675 (online)

Sebaliknya keraguan masyarakat terhadap amil zakat antara lain disebabkan amil zakat yang berafiliasi dengan partai politik dan lembaga negara yang mempunyai citra negatif (korupsi). Selain itu amil zakat belum mempunyai database mustahik yang akurat sehingga sepak terjangnya belum dirasakan secara kongkrit. Akibat ketidakpercayaan muzaki kemudian mengeluarkan zakatnya langsung kepada mustahik. Kedua, Ketidakpahaman masyarakat dalam membayarkan zakatnya ke amil zakat. Rendahnya kesadaran wajib zakat, rendahnya kepercayaan terhadap institusi zakat dan perilaku pembayar zakat yang masih amat karikatif, yaitu berorientasi jangka pendek, desentralistik dan interpersonal. Ketiga, lemahnya regulasi zakat yang mengat ur tentang penguat an zakat, baik dari kelembagaan maupun pengumpulan zakat, misalnya tidak ada sanksi bagi muzaki yang tidak membayar zakat. Berbeda dengan pajak yang jika tidak dibayar bisa dikenakan sanksi.

Sejak tahun 2016. Ada lima platform yang disediakan BAZNAS:28 Pertama, BAZNAS platform, yakni melalui website BAZNAS dan program aplikasi bernama Muzaki Corner. Kedua, Commercial Platform, yakni mengembangkan kerja sama dengan e-commerce, seperti Lazada, Shopee, Blibli, Elevenia, JD.ID. BAZNAS juga bekerja sama dengan layanan Fintech, seperti OVO, Gopay, dan lainnya. Ketiga, Social Media Platform, di mana BAZNAS mendorong iklan dan kampanye melalui sosial media untuk mengajak masyarakat berzakat, seperti Facebook, Twitter, WhatsApp, dan sebagainya. Keempat, Innovative Platform, yakni BAZNAS membuat layanan yang sifatnya inovasi yaitu melalui QR code. Kelima, Artificial Intelligence Platform, di mana BAZNAS dalam berkampanye menggunakan Chatbot pada aplikasi LINE bernama Zavira (Zakat Virtual Assistant) yang dapat ditemui di aplikasi LINE dengan nama akun baznasindonesia, dan juga donasi menggunakan Augmented Reality.

Potensi zakat digital dari tahun ke tahun mengalami peningkatan yang signifikan. Oleh karena itu BAZNAS mengembangkan strategi pengumpulan zakat digital sebagai instrumen pembayaran zakat. Pengumpulan zakat digital senantiasa mengalami peningkatan. sejak tahun 2016 sebesar 1\% namun di tahun 2019 sudah mencapai 14\% dan diperkirakan di tahun 2000 akan mencapai $30 \% .{ }^{29}$ hal ini merupakan ejawantah dari perat uran yang ditetapkan oleh Menteri Agama nomor 6 tahun 2020 dan juga fatwa MUI unt uk melakukan proses pengelolaan zakat secara tidak berkerumun. Maka pengumpulan zakat digital menjadi solusi di masa pandemik dengan adanya zakat online oleh BAZNAS dan juga Lembaga Amil Zakat dapat mempermudah masyarakat dalam menunaikan zakatnya. Lebih daripada itu zakat digital mampu menurunkan angka kemiskinan dampak masa pandemik covid 19.

Hal penting dalam zakat digital adalah penataan amil zakat. Hal ini perlu diperhatikan sejak rekrutmen awal. Karena dengan adanya Amil zakat yang melek digital nantinya mampu mendukung terhadap optimalisasi zakat digital. Sejak adanya rekrutmen petugas yang memenuhi kriteria tertentu di antaranya kemampuan teknologi menjadi hal yang utama diperhatikan. Digitalisasi zakat menjadi salah satu program yang menjadi fokus badan Amil Zakat Nasional kerjasama dengan kemitraan fundraising platform. Karena di era digital yang paling memungkinkan dilakukan adalah kolaborasi.

\footnotetext{
${ }^{28}$ https://baznas.go.id/Press Release/baca/BAZNAS Ajak Masyarakat_Zakat_Digital/531

29 https://baznas.go.id
} 
Sehingga diyakini zakat digital mampu meningkatkan pengumpulan zakat dengan menggunakan finansial teknologi sekitar 5\% dari transaksi ekonomi sehingga dapat mendorong 10\% dari keseluruhan dana zakat yang dihimpun di Indonesia. ${ }^{30}$

Pengumpulan zakat digital dengan inovasi akses digital dalam mengoptimalkan pengumpulan zakat selaras dengan tujuan syariah (maqashid syariah). Institusi zakat seperti BAZNAS yang telah melakukan program pengumpulan zakat digital bermaksud mengoptimalkan pengumpulan zakat. Dengan program zakat digital yang dijalankan oleh BAZNAS dapat meningkatkan pengumpulan zakat. Sehingga hasilnya dapat dirasakan oleh muzakki dengna menjalankan ibadah zakat secara sah. Pengumpulan zakat secara digital diharapkan muzakki dapat menjalankan ibadah dengan baik (hifz alddin), menjaga riski halal (hifz al- mal). Berikut penyajian tabel maqashid syariah terhadap pengumpulan zakat digital di masa pandemi covid 19.

\begin{tabular}{|c|c|}
\hline Tingkatan & Analisis maqasid \\
\hline Daruriyat & $\begin{array}{l}\text { Akses Zakat digital bagi muzakki tujuannya } \\
\text { untuk menunaikan kebutuhan dasar mereka di saat } \\
\text { pandemi. Kebutuhan dasar tersebut keterbatasan } \\
\text { berkumpul secara berkerumun. Dengan pemenuhan } \\
\text { kebutuhan primer tersebut akan berdampak terhadap } \\
\text { perlindungan unsur dalam tujuan Syariah yakni } \\
\text { perlindungan agama, jiwa, akal, dan harta. Dengan } \\
\text { demikian walaupun masa pandemik covid } 19 \text { penunaian } \\
\text { zakat tetap terlaksana dengan baik. }\end{array}$ \\
\hline Hajiyat & $\begin{array}{l}\text { Aspek hajiyat dimaksudkan untuk menghilangkan } \\
\text { kesulitan atau memudahkan dalam penunaian zakat. } \\
\text { Mempermudah pelaksanaan zakat digital tanpa hadir } \\
\text { langsung kepada amil, sehingga lebih efektif dan } \\
\text { efisien. dengan hajiyat ini berdampak terhadap } \\
\text { kemudahan bagi Muzakki }\end{array}$ \\
\hline Tahsiniyat & $\begin{array}{l}\text { Aspek tahsniyat dimaksudkan untuk } \\
\text { mengembangkan akses pengumpulan zakat } \\
\text { meningkatkan pengumpulan zakat. Adanya kemudahan } \\
\text { bagi muzakki dalam menunaikan zakat akan } \\
\text { memberikan motivasi dalam menunaikan zakat. Hal ini } \\
\text { juga berefek terhadap akuntabilitas dan kepercayaan } \\
\text { bagi amil zakat. Selain itu, berefek terhadap Muzakki } \\
\text { untuk senantiasa menjaga hubungan dalam ikatan amil } \\
\text { zakat dalam bentuk menerima laporan pengumpulan } \\
\text { zakat dan juga pengelolaannya. }\end{array}$ \\
\hline
\end{tabular}

\footnotetext{
${ }^{30}$ Ade Nur Rohim, "Optimalisasi Penghimpunan Zakat Melalui Digital”, Al-Balagh: Jurnal Dakwah dan Komunikasi, Vol. 4, No. 1, (2019).
} 


\section{Penutup}

Potensi pengumpulan zakat digital di Indonesia melalui platform digital senantiasa meningkat. Apalagi lagi dengan kondisi pandemik covid 19 yang memaksa masyarakat untuk mengurangi aktivitas publik yang berinteraksi secara langsung. Kerjasama institusi amil zakat dengan kemitraan fundraising platform diharapkan bermunculan muzakki baru. Kemudahan yang ditawarkan dalam akses pengumpulan zakat digital harus ditingkatkan. Selain itu performa dan kepercayaan institusi amil zakat perlu ditingkatkan dengan menjaga akuntabilitas dan transparansi. Inovasi pengumpulan zakat digital senantiasa dikembangkan dengan menyesuaikan kondisi obyektif. Asset lain yang dapat dikembangkan adalah kaum milenial. Dimana di era digital kaum milenial sudah banyak yang memiliki penghasilan untuk memenuhi nisab zakat. Hanya saja kesadaran wajib zakat harus dipahamkan terlebih dahulu. Ketika mengumpulkan zakat itu wajib dilakukan oleh amil zakat, maka mempermudah pengumpulannya juga wajib dilakukan. Hal ini sesuai dengan kaidah qa' dah fiqhiyyah: li al-wasāil hukm al-maqāsid (hukum sarana adalah sebagaimana hukum maksud yang dituju).

Bagi kalangan akademisi maupun praktisi penelitian ini penting untuk terus dipraktikan dan dikembangkan. Selanjutnya perlu dilakukan penelitian lanjutan berkaitan studi akses digital dalam pengelolaan dan pendistribusian zakat.

\section{Daftar Pustaka}

Ade, Nur Rohim. "Optimalisasi Penghimpunan Zakat Melalui Digital Fundraising". AlBalagh: Jurnal Dakwah dan Komunikasi. 4.Vol. 1. 2019.

al-Shātibìi, Abū Isḥāq. al-Muwāfaqāt fī Ușūl al-Sharī ah. vol. 2. Cairo: al-Maktabah alTijāniyah al-Kubrā, 1975

Bahrom. Hasan \& EzaniYaaqub. Pengurusan Zakat Semasa. Shah Alam: UPENA UiTM, 2006.

BAZNAS, Arsitektur Zakat Indonesia. Jakarta: Pusat Kajian Strategis BAZNAS, 2017. Djazuli, A. Kaidah-Kaidah Fiqh, cet. 3. Jakarta: Kencana 2010.

el-Ashker Ahmed, Abdel Fattah and M. Sirajul Haq (Eds). Intitutional Framework of Zakah: Dimension and Aplications. Jeddah: IRTI-IDB, 1995.

Fauzia, Amelia. "Religius Giving di Indonesia: Studi Kasus Filantropi Islam", DIALOG , No. 69, 2010.

Imtiazi, I.a .et al. (eds). Management of Zakah in Modern Muslim Society. Jeddah: IRTIIDB, 1989.

Ismartono, "Filantropi dalam Dunai Kristen" dalam Idris Thaha, (ed.) Berderma Untuk Semua, Praktik dan Wacana Filantropi Islam. Jakarta: Teraju 2003.

Isvadiary, Rika."Penerapan Obligatory System Dalam Pengelolaan Zakat Di Indonesia", Jurnal Syari 'ah LKIHI, Edisi II. 2010.

Juegensmeyer, Mark dan Darrin McMahon. Philantropy in the World's Traditions. Bloomington: Indoana University Press, 1998.

Landesman, Alter F. Jewish Social Work Today Religion and Social Work. New York: The Institut for Religious and Social Studies, 1956. 
Mubarok, Abdulloh dan Baihaqi Fanani. "Penghimpunan Dana Zakat Nasional: Potensi, Realisasi dan Peran Penting Organisasi Pengelola Zakat”, PERMANA - Vol . V No.2, 2014.

PEBS-FEUI. Indonesia Shari'ah Economic Outlook (ISEO). Jakarta: Lembaga Penerbit FEUI, 2011.

Qoḥ̂, Mundhir. "Taḥ̣ịil wa Tawzī' al Zakāh Tajrubah al Mamlakah al 'Arabiyah al Su'ūdiyah" dalam al Mawād al 'Ilmìyah li Barnāmij al Tadrīb 'Alā Tatbiq al Zakāh fí al Mujtama' al Islāmī al Mu'āṣir. Jedah: al Bank al Islāmì li al Tanmīyah, 1983

Quṭb, Sayyid. al 'Adālah al Ijtimàìiyah fĩ al Islām. Cet. VI. Bayrūt: Dār al Shurūq, 1979.

Rahman, Holilur. Regulasi Zakat: Studi Kewenangan Amil Zakat Di Indonesia. Tangerang Selatan: Yasmi, 2018.

Rais, M. Amin. Tauhid Sosial Formula Menggempur Kesenjangan. Bandung: Mizan, 1998.

Rohim, Ade Nur. "Optimalisasi Penghimpunan Zakat Melalui Digital”. Al-Balagh: Jurnal Dakwah dan Komunikasi, Vol. 4, No. 1, 2019.

Sadeq, Abu al-Hasan. A Survey of the Intitutional Of Zakah: Issues, Theories and Administration. Jeddah: IRTI-IDB, 1994.

Saefuddin, AM. Membumikan Ekonomi Islam. Jakarta: PT. PPA Consultants, 2011.

Salama, Abidin Ahmad. Obligatory vs Nonobligatory Zakah System, Institusional Framework of Zakah: Dimension and Applications. Jeddah: Islamic Research and Training Institute of Islamic Development Bank, 1990.

Sector, Independent Giving and Volunteering un the United States. Washington D.C.: Independent Sector, 2001.

Tarimin, Mujani. Tanggungjawab Amil dalam Konteks Kontemporari, Kertas Kerja 10, Zakat Menuju Pengurusan Profesional. Kualalumpur: Utusan Publications \& Distributor, 2005.

Wibisono, Yusuf. Mengelola Zakat di Indonesia: Diskursus Pengelolaan Zakat dari Rezim Undang-Undang Nomor 38 tahun 1999 ke Rezim Undang-Undang Nomor 23 tahun 2011. Jakarta: Prenadamedia Group, 2015.

https://baznas.go.id.

https://cafonline.org

https://www.idntimes.com 